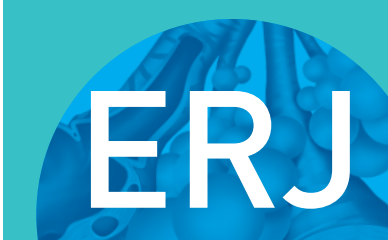

open research
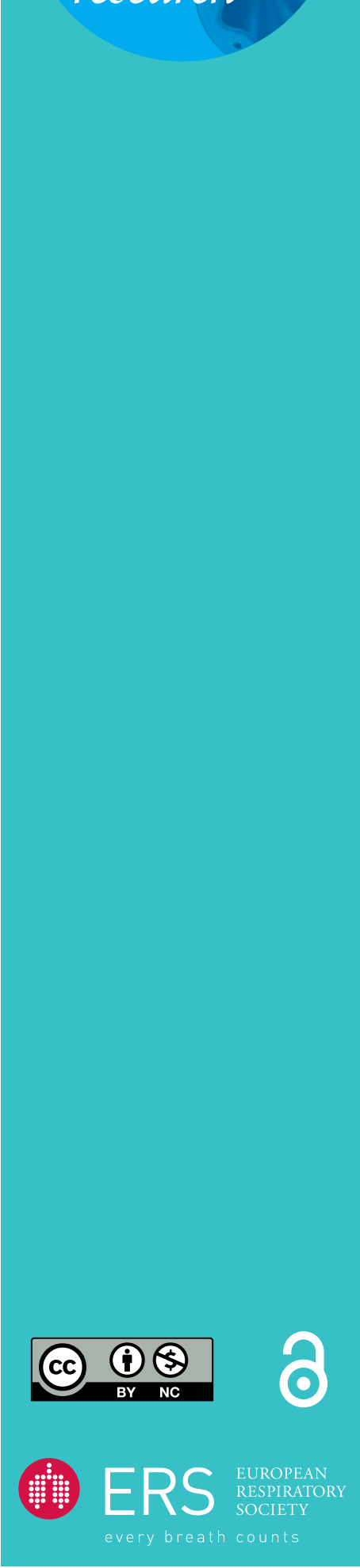

\section{Differential diagnosis and treatment approach to pulmonary artery sarcoma: a case report and literature review}

\section{To the Editor:}

Pulmonary artery sarcoma (PAS) is a rare tumour that originates from the intimal layer of the pulmonary trunk and pulmonary arteries. Diagnosis of PAS is challenging, since it can be difficult to distinguish from a pulmonary embolism. The evidence regarding diagnostic techniques, management of the disease and prognosis is limited to a small series of cases and case reports $[1,2]$.

Herein, we report the case of a patient initially diagnosed with pulmonary embolism by computer tomography (CT) in which the suspicion of an underlying process was suspected due to the insidious clinical presentation. Further imaging studies led to the diagnosis of PAS.

This study was conducted in accordance with the declaration of Helsinki and with signed informed consent from the patient.

A 70-year-old woman had previous history of breast cancer and was in complete remission following treatment 7 years before surgery, radiotherapy and hormonal blockade. She also had previous episodes of superficial vein thrombosis. She presented with an 8-month history of anorexia, weight loss, dyspnoea on exertion and pleuritic pain in the left hemithorax.

A chest radiograph showed pulmonary infiltrates and she was treated with antibiotics. Due to the persistence of symptoms, a CT scan was performed showing an increased diameter of pulmonary arteries with massive thrombosis affecting the main trunk and left lung with extension to lobar, segmental and subsegmental arteries (figure 1). Laboratory tests revealed D-dimer $188 \mathrm{ng} \cdot \mathrm{mL}^{-1}$ and haemoglobin $11.1 \mathrm{~g} \cdot \mathrm{dl}^{-1}$; the remainder were unremarkable. A doppler ultrasound of lower extremities ruled out deep vein thrombosis (DVT). A transthoracic echocardiogram revealed a dilated right ventricle with preserved systolic ejection fraction, systolic pressure of the pulmonary artery of $69 \mathrm{mmHg}$ and an obstructive gradient in the trunk of the pulmonary artery secondary to an obstructive lesion.

A magnetic resonance angiography showed a heterogeneous mediastinal mass located at the bifurcation of the pulmonary trunk, with extension to both pulmonary arteries with extravascular extension and ganglionar, pleural, vertebral and thoracic metastatic dissemination. Fluorodeoxyglucose-positron emission tomography (FDG-PET) scan revealed a pathological deposit that affected the main and the left pulmonary artery and the right intermediary artery without pathological uptakes at any other level.

A biopsy of the pulmonary artery mass was ruled out due to high risk of complications.

Assuming the diagnosis of PAS, cytoreductive chemotherapy with epirubicin plus ifosfamide was initiated. After the first cycle there was evidence of tumour progression with the appearance of pulmonary metastases, so treatment was changed to gemcitabine-docetaxel with stable disease during the next 8 months of follow-up.

PAS is an uncommon and aggressive malignant tumour which originates from the intimal layer of the pulmonary trunk and pulmonary arteries. The true incidence of this entity is unknown and might be

@ERSpublications

Pulmonary artery sarcoma is an aggressive tumour that originates from the intimal layer of the pulmonary trunk and pulmonary arteries. Clinical presentation may resemble a pulmonary embolism. Prompt diagnosis is necessary to improve survival. https://bit.ly/2xZwENm

Cite this article as: Cervilla-Muñoz E, Galeano-Valle F, Del-Toro-Cervera J, et al. Differential diagnosis and treatment approach to pulmonary artery sarcoma: a case report and literature review. ERJ Open Res 2020; 6: 00124-2020 [https://doi.org/10.1183/23120541.00124-2020].

Copyright $\odot$ ERS 2020. This article is open access and distributed under the terms of the Creative Commons Attribution NonCommercial Licence 4.0. 
FIGURE 1 a) Chest computed tomography showing an increased diameter of pulmonary arteries with massive thrombosis affecting the main trunk and left lung with extension to lobar, segmental and subsegmental arteries. b) Fluorodeoxyglucosepositron emission tomography showing pathological deposit affecting the main and left pulmonary artery and the right intermediary artery. PT: pulmonary trunk; RPA: right pulmonary artery; LPA: left pulmonary artery.

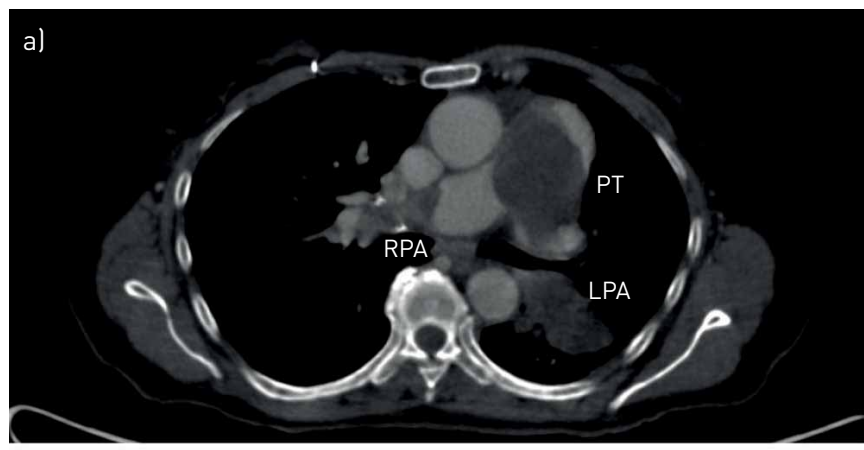

b)

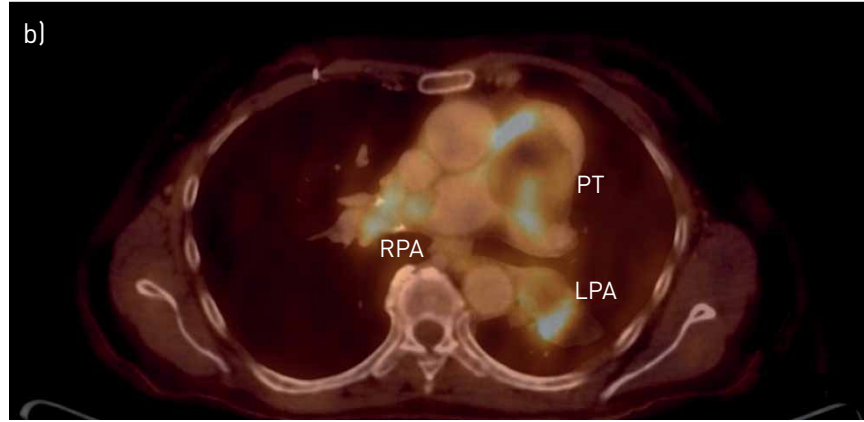

underestimated, as it is frequently misdiagnosed and therefore underreported. Its diagnosis is challenging, since it can be easily confused with pulmonary embolism [1]. The mean (range) age of diagnosis is 55 (24-74) years with no differences in prevalence or outcomes between sexes [2, 3]. Table 1 shows the case series of PAS published in the past 5 years.

Clinical presentation of PAS usually includes dyspnoea, cough, haemoptysis, chest pain or syncope. CT images, insidious onset of symptoms, absence of DVT and persistent symptoms despite anticoagulation should raise the suspicion of PAS [9]. The acute obstruction in the right ventricle outflow tract in the case of pulmonary embolism more frequently results in hypotension and shock, whereas a more progressive progression in cases of PAS leads to a haemodynamically well-tolerated obstruction and the development of pulmonary hypertension [2]. Other findings such as constitutional symptoms and elevated serum inflammatory markers might also be present $[2,5]$. Although $\mathrm{D}$-dimer levels usually remain within normal ranges, there have been case reports in which different elevations in D-dimer values have been described. This has been associated with the presence of concomitant thrombosis around the tumour as D-dimer levels rapidly normalise after the initiation of anticoagulant or thrombolytic therapy $[6,10]$. As stated before, the clinical presentation of PAS is insidious with a median period between the onset of symptoms and the diagnosis of usually $>2-3$ months $[2,9]$. In several case series, an initial diagnosis of pulmonary embolism was made in approximately half of the patients $[4,6,7]$. Elevated pulmonary hypertension is associated with increased mortality (HR 9.5, 95\% CI 1.8-50.3) but interestingly, no differences in mortality rates were described between patients correctly diagnosed and those initially diagnosed as pulmonary embolism [7].

Imaging studies for the diagnosis of PAS include echocardiogram, CT pulmonary angiography and magnetic resonance imaging (MRI). Additional techniques such as angiography and positron emission tomography are also useful. In CT pulmonary angiography, pulmonary artery sarcoma appears as lesions with rounded, bulged or lobulated surfaces, non-homogenous attenuation from haemorrhage and filling defects with increased diameter of the pulmonary arteries and soft tissue characteristics. Additionally, it is occasionally associated with extravascular dissemination. However, pulmonary embolism usually appears as filling defects with uniform intensities $[5,11]$. In recent years, MRI has become the preferred technique to differentiate PAS from acute and chronic pulmonary embolism. Pulmonary sarcoma will typically enhance with gadolinium contrast compared to thrombus and the degree of enhancement appears to have a correlation with tumour differentiation. MRI allows the identification of soft tissues of the PAS tumour within the lumen, its extensions and the identification of pulmonary valve involvement [5, 9]. FDG-PET has emerged as a useful technique for diagnosis and staging of the disease as the increased FDG uptake may confirm the malignant nature of the tumour and identification of metastasis [11, 12]. Echocardiography is used for the evaluation of the right ventricle outflow tract, pulmonary valve involvement (in about $30 \%$ of the cases) and the presence of pulmonary hypertension [9, 11]. A diagnostic and treatment algorithm is suggested in figure 2. 


\begin{tabular}{|c|c|c|c|c|c|c|c|}
\hline $\begin{array}{l}\text { First author } \\
\text { [ref.] }\end{array}$ & Patients & $\begin{array}{l}\text { Age at } \\
\text { diagnosis } \\
\text { years }\end{array}$ & Clinical presentation & Histological type & Treatment & $\begin{array}{l}\text { Median } \\
\text { survival } \\
\text { time }\end{array}$ & $\begin{array}{l}\text { Patients initially } \\
\text { diagnosis of } \mathrm{PE}^{\#}\end{array}$ \\
\hline SRIVALI [1] & $9(4 \mathrm{M} / 5 \mathrm{~F})$ & $55(24-74)$ & $\begin{array}{c}\text { Dyspnoea: } 9 \text { (100) } \\
\text { Cough: } 2 \text { (22) } \\
\text { Syncope/presyncope: } 2 \text { (22) } \\
\text { Haemoptysis: } 1 \text { (11) }\end{array}$ & $\begin{array}{c}\text { High-grade spindle cell sarcoma }=2 \\
\text { Intermediate-grade spindle-cell } \\
\text { sarcoma }=1 \\
\text { High-grade undifferentiated } \\
\text { pleomorphic spindle-cell } \\
\text { sarcoma }=1 \\
\text { Myxofibrosarcoma }=1 \\
\text { Angiosarcoma }=1 \\
\text { Intermediate-grade myofibroblastic } \\
\text { sarcoma }=1 \\
\text { Intimal sarcoma }=2\end{array}$ & $\begin{array}{c}\mathrm{SR}=1 \\
\mathrm{SR}+\mathrm{RT}=3 \\
\mathrm{SR}+\mathrm{CT}=3 \\
\mathrm{SR}+\mathrm{RT}+\mathrm{CT}=2 \\
\text { None }=1\end{array}$ & 23.6 months & 7 \\
\hline YIN [4] & $12(5 \mathrm{M} / 7 \mathrm{~F})$ & $51.2(21-73)$ & $\begin{array}{l}\text { Chest pain: } 7 \text { (83) } \\
\text { Asthenia: } 7 \text { (58) } \\
\text { Cough: } 6 \text { (50) } \\
\text { Syncope: } 3(25) \\
\text { Haemoptysis: } 2(16) \\
\text { Headache: } 2 \text { (16) } \\
\text { Hoarseness: } 1(8)\end{array}$ & $\begin{array}{c}\text { Undifferentiated pleomorphic } \\
\text { sarcoma }=3 \\
\text { Myofibroblastic differentiation=6 } \\
\text { Leiomyosarcoma }=1 \\
\text { Synovial sarcoma }=1 \\
\text { Rhabdomyosarcoma }=1\end{array}$ & $\begin{array}{c}\text { PEA }=7 \\
\text { PEA+pneumonectomy }=3 \\
\text { Exploratory } \\
\text { thoracotomy }=2 \\
\text { CT+RT }=4 \\
\text { CT }=2 \\
\text { RT: } 1 \\
\text { None }=5\end{array}$ & 18 months & 6 \\
\hline Pu [5] & $9(4 \mathrm{M} / 5 \mathrm{~F})$ & $46.1 \pm 10.9$ & $\begin{array}{c}\text { Dyspnoea: } 8 \text { (89) } \\
\text { Syncope: } 3 \text { (33) } \\
\text { Palpitations: } 2 \text { (22) } \\
\text { Chest pain: } 2 \text { (22.2) } \\
\text { Haemoptysis: } 1 \text { (11) } \\
\text { Fever: } 4 \text { (44) } \\
\text { Fatigue: } 5 \text { (56) } \\
\text { Weight loss: } 5 \text { (56) }\end{array}$ & $\begin{array}{c}\text { Intimal sarcoma }=4 \\
\text { Leiomyosarcoma }=3 \\
\text { Pleomorphic rhabdomyosarcoma }=1 \\
\text { Undifferentiated sarcoma }=1\end{array}$ & $\begin{array}{c}\mathrm{PEA}=5 \\
\mathrm{PEA}+\mathrm{RT}=2 \\
\mathrm{PEA}+\mathrm{CT}=1 \\
\mathrm{PEA}+\mathrm{RT}+\mathrm{CT}=1\end{array}$ & 8.4 months & 7 \\
\hline Deng [6] & $13(6 \mathrm{M} / 7 \mathrm{~F})$ & $45(26-79)$ & $\begin{array}{c}\text { Dyspnoea: } 13 \text { (100) } \\
\text { Syncope: } 6 \text { (46) } \\
\text { Chest pain: } 5 \text { (38) } \\
\text { Haemoptysis: } 4 \text { (31) } \\
\text { Fever: } 3 \text { (23) }\end{array}$ & $\begin{array}{c}\text { Intimal sarcoma }=9 \\
\text { steosarcoma }=1 \\
\text { Undifferentiated } \text { pleomorphic } \\
\text { sarcoma }=1 \\
\text { Atypical borderline cartilage tumour/ } \\
\text { sarcoma }=1 \\
\text { Malignant solitary fibrous tumour }=1\end{array}$ & $\begin{array}{c}\mathrm{SR}=5 \\
\mathrm{SR}+\mathrm{CT}=7 \\
\mathrm{SR}+\mathrm{RT}=1\end{array}$ & 20.2 months & 8 \\
\hline
\end{tabular}




\begin{tabular}{|c|c|c|c|c|c|c|c|}
\hline $\begin{array}{l}\text { First author } \\
\text { [ref.] }\end{array}$ & Patients & $\begin{array}{l}\text { Age at } \\
\text { diagnosis } \\
\text { years }\end{array}$ & Clinical presentation & Histological type & Treatment & $\begin{array}{l}\text { Median } \\
\text { survival } \\
\text { time }\end{array}$ & $\begin{array}{l}\text { Patients initially } \\
\text { diagnosis of } \mathrm{PE}^{\#}\end{array}$ \\
\hline Lee [7] & $20(10 \mathrm{M} / 10 \mathrm{~F})$ & $54(33-75)$ & $\begin{array}{l}\text { Dyspnoea: } 13(65) \\
\text { Chest pain: } 5(25) \\
\text { Cough: } 4(20) \\
\text { Haemoptysis: } 3(15) \\
\text { Syncope: } 2(10) \\
\text { Asymptomatic: } 2(10)\end{array}$ & $\begin{array}{c}\text { Spindle cell sarcoma }=8 \\
\text { Intimal sarcoma }=4 \\
\text { Pleomorphic sarcoma }=3 \\
\text { High grade sarcoma }=2 \\
\text { Chondroid differentiation }=1 \\
\text { Angiosarcoma }=1 \\
\text { Smooth muscle differentiation }=1\end{array}$ & $\begin{array}{c}\mathrm{SR}=6 \\
\mathrm{SR}+\mathrm{QT}=3 \\
\mathrm{SR}+\mathrm{RT}=5 \\
\mathrm{SR}+\mathrm{RT}+\mathrm{QT}=3 \\
\text { None=3 }\end{array}$ & 24 months & 10 \\
\hline Wong [8] & 20 (11 M/9 F) & 57 (27-77) & $\begin{array}{c}\text { Dyspnoea: } 20 \text { (100) } \\
\text { Chest pain/tightness: } 7 \text { (35) } \\
\text { Dependent oedema: } 5 \text { (25) } \\
\text { Constitutional symptoms: } 5 \text { (25) } \\
\text { Cough: } 3 \text { (15) } \\
\text { Haemoptysis: } 3 \text { (15) }\end{array}$ & $\begin{array}{c}\text { Intimal sarcoma=13 } \\
\text { High-grade sarcoma=6 } \\
\text { No biopsy=1 }\end{array}$ & $\begin{array}{c}\mathrm{PEA}=14 \\
\mathrm{PEA}+\mathrm{CT}=5 \\
\mathrm{PEA}+\mathrm{RT}=4 \\
\mathrm{CT}=5 \\
\mathrm{RT}=5 \\
\text { Radiofrequency } \\
\text { ablation=1 }\end{array}$ & 17 months & \\
\hline $\begin{array}{l}\text { BANDYOPADHYAY } \\
\text { [2] }\end{array}$ & $10(8 \mathrm{M} / 2 \mathrm{~F})$ & $47 \pm 11.3$ & & $\begin{array}{c}\text { Leiomyosarcoma }=1 \\
\text { Spindle cell sarcoma }=2 \\
\text { Angiosarcoma }=3 \\
\text { Myofibroblastic sarcoma }=1 \\
\text { Osteosarcoma }=2 \\
\text { Rhabdomyosarcoma }=1\end{array}$ & & 21.6 months & \\
\hline
\end{tabular}




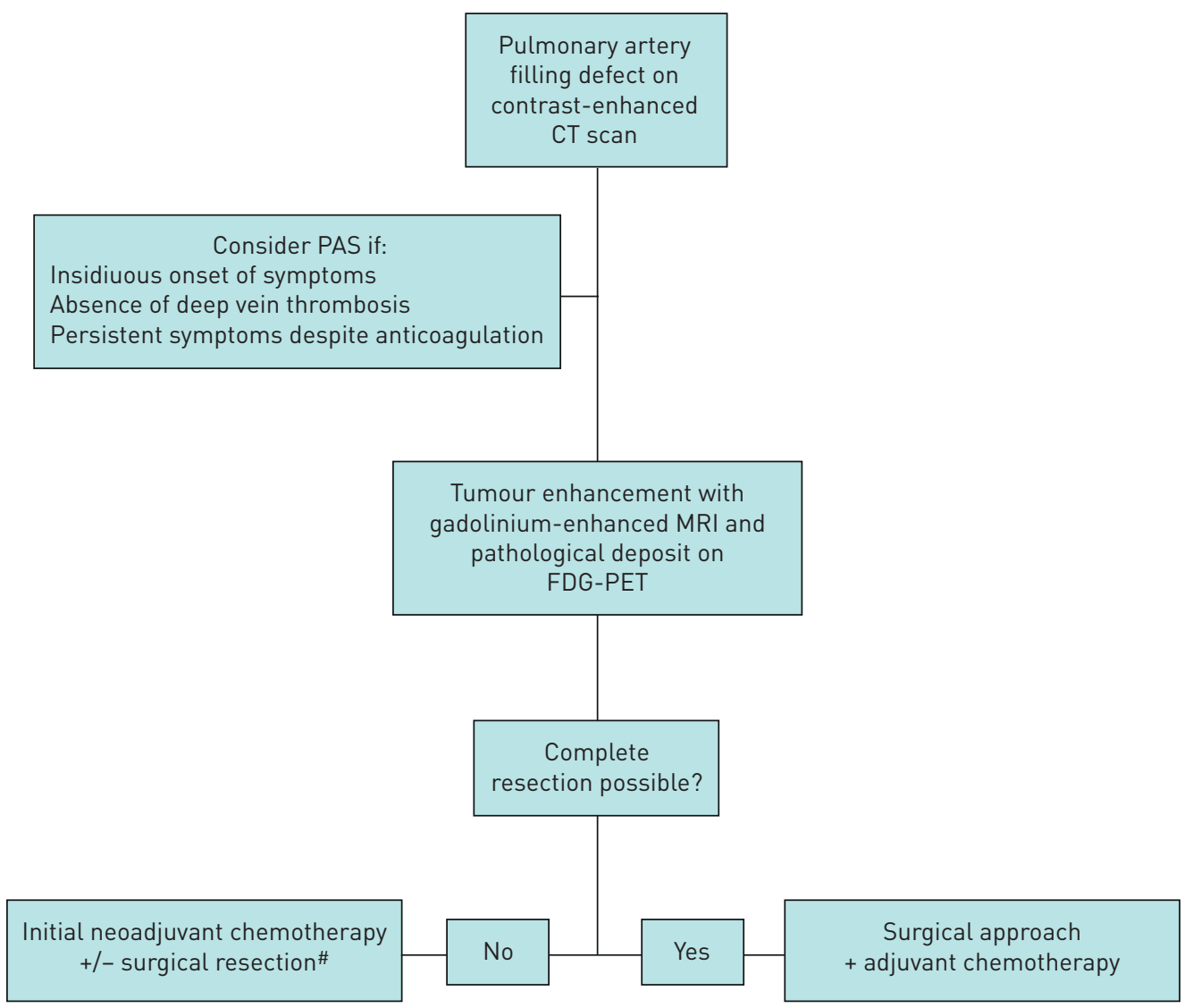

FIGURE 2 Diagnostic and treatment algorithm. CT: computed tomography; PAS: pulmonary artery sarcoma; MRI: magnetic resonance imaging; FDG-PET: fluorodeoxyglucose-positron emission tomography. \#: consider pulmonary endarterectomy to palliate symptoms of pulmonary hypertension if surgical resection not possible.

The histopathological classification includes: rhabdomyosarcoma, osteogenic sarcoma, angiosarcoma, fibrosarcoma, malignant mesenchymoma, myxosarcoma, chondrosarcoma, osteosarcoma, malignant fibrous histiocytoma, liposarcoma and unclassified leiomyosarcoma [2, 3, 9]. No clear differences in survival rates have been found in previous reports according to the histological type. Preoperative samples for anatomopathological studies can be obtained through angiography, percutaneous needle aspiration or endobronchial ultrasound-guided transbronchial needle aspiration [6].

Along different series, surgery plus adjuvant/neoadjuvant chemotherapy has been demonstrated to achieve best survival rates [2, 3, 11]. However, despite adequate treatment, the overall prognosis is poor (1.5 months without treatment versus $8-36$ months with treatment) $[3,5,8]$. Surgical approaches include pneumonectomy, lobectomy, tumour resection, tumour endarterectomy and heart/lung transplantation. Complete resection has been shown to improve survival compared to partial resections or pulmonary endarterectomy, as pulmonary endarterectomy rarely reaches complete free resection margins [2, 11]. In a review of 20 cases, Wong et al. [8] found no differences in terms of survival in the follow-up of patients in whom pulmonary endarterectomy was performed compared to those who did not, but significant improvement of symptoms and pulmonary hypertension in these patients was observed. Unfortunately, many patients are not candidates to undergo complete resections or even palliative resections, which would depend on the cardiopulmonary reserve, the presence of metastatic disease or resectability. Therefore, initial neoadjuvant chemotherapy is usually recommended in stable patients to achieve tumour shrinkage and resectability $[9,11]$. In addition, chemotherapy seems to reduce the risk of metastatic disease during follow-up, although it does not seem to affect local recurrences [2]. Chemotherapy regimens include epirubicin (or pegylated liposomal doxorubicin) plus ifosfamide. Pazopanib (a tyrosine kinase inhibitor) is the only targeted agent approved for soft tissue sarcoma but it lacks clinical experience in this type of tumour $[6,11]$.

PAS is an aggressive malignant tumour, which is difficult to differentiate from a pulmonary embolism as they share similar clinical manifestations. Regardless of a prompt diagnosis and early treatment, the 
prognosis of this disease remains poor. A multidisciplinary approach is essential to increase survival and improve the quality of life.

Eva Cervilla-Muñoz $\circledast^{1,2}$, Francisco Galeano-Valle ${ }^{1,2,3}$, Jorge Del-Toro-Cervera ${ }^{1,2,3}$, Enrique Calleja-Cartón ${ }^{4}$ and Pablo Demelo-Rodríguez ${ }^{1,2,3}$

${ }^{1}$ Venous Thromboembolism Unit, Internal Medicine. General University Hospital Gregorio Marañón, Madrid, Spain. ${ }^{2}$ Dept of Medicine, School of Medicine, Universidad Complutense, Madrid, Spain. ${ }^{3}$ Gregorio Marañón Health Research Institute, Madrid, Spain. ${ }^{4}$ Vascular Radiology, Hospital General Universitario Gregorio Marañón Gregorio Marañón, Madrid, Spain.

Correspondence: Eva Cervilla-Muñoz, Hospital General Universitario Gregorio Marañón, C/. Doctor Esquerdo, 46, 28007, Madrid, Spain. E-mail: e.cervilla.munoz@gmail.com

Received: 8 March 2020 | Accepted after revision: 5 May 2020

Acknowledgements: This work was previously presented as an electronic poster at the 18th European Congress of Internal Medicine (Lisbon, Portugal) 29 to 31 August, 2019.

Conflict of interest: None declared.

\section{References}

1 Srivali N, Yi ES, Ryu JH. Pulmonary artery sarcoma mimicking pulmonary embolism: a case series. QJM 2017; 110: 283-286.

2 Bandyopadhyay D, Panchabhai TS, Bajaj NS, et al. Primary pulmonary artery sarcoma: a close associate of pulmonary embolism-20-year observational analysis. J Thorac Dis 2016; 8: 2592-2601.

3 Mussot S, Ghigna MR, Mercier O, et al. Retrospective institutional study of 31 patients treated for pulmonary artery sarcoma. Eur J Cardiothorac Surg 2013; 43: 787-793.

4 Yin K, Zhang Z, Luo R, et al. Clinical features and surgical outcomes of pulmonary artery sarcoma. $J$ Thorac Cardiovasc Surg 2018; 155: 1109-1115.

$5 \mathrm{Pu} \mathrm{X}$, Song M, Huang X, et al. Clinical and radiological features of pulmonary artery sarcoma: a report of nine cases. Clin Respir J 2018; 12: 1820-1829.

6 Deng L, Zhu J, Xu J, et al. Clinical presentation and surgical treatment of primary pulmonary artery sarcoma. Interact Cardiovasc Thorac Surg 2018; 26: 243-247.

7 Lee $\mathrm{Y}$, Kim $\mathrm{HJ}$, Yoon $\mathrm{H}$, et al. Clinical characteristics and treatment outcomes of primary pulmonary artery sarcoma in Korea. J Korean Med Sci 2016; 31: 1755-1760.

8 Wong HH, Gounaris I, McCormack A, et al. Presentation and management of pulmonary artery sarcoma. Clin Sarcoma Res 2015; 5: 3.

9 Blackmon SH, Rice DC, Correa AM, et al. Management of primary pulmonary artery sarcomas. Ann Thorac Surg 2009; 87: 977-984.

10 Sakai K, Minoura Y, Matsui T, et al. Primary pulmonary artery intimal sarcoma case with elevated coagulation markers. J Clin Diagn Res 2017; 11: OD10-OD11.

11 Grazioli V, Vistarini N, Morsolini M, et al. Surgical treatment of primary pulmonary artery sarcoma. $J$ Thorac Cardiovasc Surg 2014; 148: 113-118.

12 Tueller C, Fischer Biner R, Minder S, et al. FDG-PET in diagnostic work-up of pulmonary artery sarcomas. Eur Respir J 2010; 35: 444-446. 